\title{
Evaluation of Iron Status by Bone Marrow Iron Stain and its Correlation with Serum Iron Profile in Chronic Kidney Disease (CKD)
}

\author{
MM RAHMAN ${ }^{\mathrm{a}}$, PK DUTTA ${ }^{\mathrm{b}}, \mathrm{M} \mathrm{HOQUE}^{\mathrm{c}}$, MIH KHAN ${ }^{\mathrm{d}}$, D BANIK ${ }^{\mathrm{e}}$, AK DUTTA $^{\mathrm{f}}$, \\ MU HASAN ${ }^{g}$, EB YUNUS ${ }^{\mathrm{h}}$, ABM YUNUS ${ }^{\mathrm{i}}$, MJ RAHMAN ${ }^{\mathrm{J}}$
}

\section{Summary:}

This observational study was done on 52 cases of predialysis chronic kidney disease (CKD) patients with chronic anaemia. The aim of the study was to determine the tissue iron status, comparison of the tissue iron with serum iron profile and justification of giving iron in chronic kidney disease (CKD) patients on the basis of serum iron profile. Bone marrow iron stain was done in each case and compared with the serum iron profile. The mean age of the patients was $46.8 \pm 12.6$ years and the mean haemoglobin and serum creatinine levels of the study population were $9.36 \pm 2.13 \mathrm{gm} / \mathrm{dl}$ and $8.0 \pm 4.2$ $m g / d l$ respectively. Stainable iron deposits were present in 40 (77\%) cases. The mean serum ferritin and transferin saturation (TSAT) of the 52 cases were found to be 412.9 $\mathrm{ng} / \mathrm{ml}$ and $28.3 \%$ and that for the 12 iron deficient cases were $101.8 \mathrm{ng} / \mathrm{ml}$ and $23.8 \%$. Over all normal $>100 \mathrm{ng} / \mathrm{ml}$

\section{Introduction:}

Iron deficiency whether absolute or functional is an important cause of anaemia in patients with chronic kidney disease ${ }^{1}$. Iron deficiency anaemia is treated

a. Dr. Md. Mahbubur Rahman, FCPS, Assistant Professor, Dept. of Haematology, NICRH.

b. Dr. Pradip Kumar Dutta, FCPS, MD, Assistant Professor, Dept. of Nephrology, CMCH.

c. Professor Mahmudul Hoque, M Phil, Professor, Dept. of Biochemistry, $\mathrm{CMCH}$.

d. Dr. Md. Iftikher Hossain Han, MD, Registrar, Dept. of Nephrology, $\mathrm{CMCH}$.

e. Dr. Dhiman Banik, MD, MO, Dept. of ENTD, CMCH.

f. Dr. Asok Kumar Dutta, FCPS, Jr. Consultant, Dept. of Medicine, $\mathrm{CMCH}$.

g. Dr. Mahtab Uddin Hasan, FCPS, MRCP, Associate Professor, Dept. of Medicine, CMCH.

h. Professor Emran Bin Yunus, FCPS, FRCP, Professor, Dept. of Nephrology, CMCH.

i. Professor ABM Yunus, M Phil, FCPS, Professor, Dept. of Haematology, BSMMU.

j. Professor Md. Jaliolur Rahman, M Phil, FCPS, FRCP, Chairman, Dept. of Haematology, BSMMU.

Address of correspondence: Dr. Md. Mahbubur Rahman, FCPS, Assistant Professor, Dept. of Haematology, NICRH.

Received: 8 October, 2006

Accepted: 4 June, 2007
$<500 \mathrm{ng} / \mathrm{ml})$, increased (>500ng/ml) or low $(<100 \mathrm{ng} / \mathrm{ml})$ serum ferritin was found in 28 and 15 and nine cases respectively. On the other hand, normal $(>20 \%<50 \%)$ and low (<20\%) TSAT were found in 31 and 12 cases, and high TSAT (>50\%) in only nine cases. Out of the 12 cases having no evidence of stainable iron in the marrow low serum ferritin and low TSAT were found in eight (66.6\%) and six (50\%) cases, and high TSAT and either normal or high serum ferritin in six (50\%) \& four (33.3\%) cases respectively. Low TSAT was also found in six (15\%) cases of those having iron deposits in the marrow. It is, therefore, concluded that absence of stainable iron in the bone marrow is a better evidence of iron depletion than the serum iron profile and that serum ferritin and TSAT correlate less well with the bone marrow iron status in patient with chronic kidney disease.

(J Bangladesh Coll Phys Surg 2007; 25 : 117-120)

either by oral or parenteral iron therapy, or by blood transfusion. Improvement of hemoglobin level in CKD improves performance status, reduces disease progression and decreases the rate of morbidity and mortality ${ }^{2}$. On the other hand, increased tissue iron can aggravate disease progression by precipitation of infection and generation of hyper-reactive free radical mediated tissue injury ${ }^{3,4}$. Therefore, it is important to know the exact body iron status in CKD patients for the proper management of the patients. In normal healthy individual iron is stored in the liver, muscle and bone marrow. Bone marrow iron is contained mainly in the macrophages that release it to the developing erythron for the synthesis of haemoglobin.

Low serum iron, low serum ferritin, low TSAT and high concentration of transferin indicate iron deficiency. Serum ferritin level and TSAT are usually considered as corner stone for the diagnosis of iron deficiency. Though serum ferritin of less than 100 $\mathrm{ng} / \mathrm{ml}$ and a STAT of less than $20 \%$ indicate iron deficiency in CKD, these two parameters fail to detect functional iron deficiency in all cases of CKD patients $5,6,7$. Increase in serum ferritin without actual 
changes in storage iron commonly occurs in a chronic disease ${ }^{8}$. Chronic renal failure (CRF) with occult infection may cause increased serum ferritin level irrespective of the actual iron storage. On the other hand, transferin saturation may also be misleading since nutritional status and loss in urine in nephrosis can affect transferin concentration in CRF 9, 10. So, TSAT may decrease to a level consistent with iron deficiency yet serum iron may be normal or even elevated 7 . Tissue iron stain provides an important tool to evaluate the actual iron status in the body. In absolute iron deficiency no stainable iron can be detected in the tissue. Absence of stainable iron in the bone marrow is accepted as a gold standard for absolute iron deficiency ${ }^{10}$. In this study, the actual iron status in CKD patients was evaluated by detecting the stainable iron in the bone marrow and it was compared with biochemical parameters of serum iron.

\section{Materials and Methods}

This descriptive observational study was conducted in the Nephrology unit of Chittagong Medical College Hospital. A total of $52 \mathrm{CKD}$ patients due to various causes with chronic anemia were included in this study (Fig-1). There were 34 male and 18 female patients. The age ranges of the patients were between 23 and 75 years. The inclusion criteria were predialysis CKD patients with chronic anaemia having no history of active bleeding and who had never been treated with rHuEPO. CKD patients having a hemolytic disorder or primary hemosiderosis were excluded from the study. The characteristics of the patients are shown in Table-1.

The bone marrow was collected from the iliac crest with the help of a 'Salah' bone marrow aspiration needle under local anaesthesia. Subsequently, bone marrow iron was detected by 'Prussian blue' stain on smear prepared with definite marrow fragment whereby presence of siderotic granules in the macrophages appeared as either blue black dots or clumps. Scoring of stainable iron deposits in the marrow was done as 'absent' if such blue-black dot and/or clump were absent or as 'present' if such dots or clumps were present. At the same time, serum iron profile that includes the estimations of serum iron, total iron binding capacity (TIBC), serum ferritin and percent saturation of transferin (TSAT) were determined. Serum iron and TIBC were estimated by 'spectrophotometric' method (Photometer 5010, GMBH, Germany) where as Serum ferritin level was determined by 'chemiluminescence' method (IMMULYTE One System, DPC, USA). TSAT was calculated from the 'serum iron' and 'TIBC' in each case. The results were recorded in printed form and subsequently analyzed.

\section{Results:}

A total of $52 \mathrm{CKD}$ patients were included in this study. There were 34 (65.4\%) males and 18 (34.6\%) females with a male to female ratio of $1.8: 1$. The mean age of the patients was $46.8 \pm 12.6$ years (range $23-75$ years) and the mean haemoglobin and serum creatinine levels were $9.36 \pm 2.13 \mathrm{gm} / \mathrm{dl}$ and $8.0 \pm 4.2$ $\mathrm{mg} / \mathrm{dl}$ respectively. Out of these 52 patients stainable iron deposits were detected in $40(77 \%)$ patients and the rest $12(23 \%)$ patients had no stainable iron in the marrow. The mean serum iron, TIBC, serum ferritin and TSAT of the 52 cases were found to be 115.3 $\mathrm{ug} / \mathrm{dl}, 421.9 \mathrm{ug} / \mathrm{dl}, 412.9 \mathrm{ng} / \mathrm{ml}$ and $28.3 \%$ respectively while in those of the 12 patients with no stainable iron in the marrow were found to be 114.5 $\mathrm{ug} / \mathrm{dl}, 417 \mathrm{ug} / \mathrm{dl}, 101.8 \mathrm{ng} / \mathrm{ml}$ and $23.8 \%$ respectively (Table-II). Out of the 40 patients who had stainable iron deposits in the marrow, only one patient had low $(<100 \mathrm{ng} / \mathrm{ml})$ serum ferritin, 14 patients had high $(>500 \mathrm{ng} / \mathrm{ml})$ serum ferritin and 25 patients had serum ferritin level within the therapeutic range (100 $-500 \mathrm{ng} / \mathrm{ml}$ ). On the other hand, out of the 12 patients with no stainable iron in the marrow eight patients had low serum ferritin, one patient had high serum ferritin and three patients had serum ferritin level within the therapeutic range. Low $(<20 \%)$, high $(>50 \%)$ and therapeutic range $(20-50 \%)$ of TSAT were found in 6,3 , and 31 of those patients having detectable iron in the marrow where as low and high TSAT were found in equal number of 12 patients having no detectable iron deposits in the marrow (Table-III).

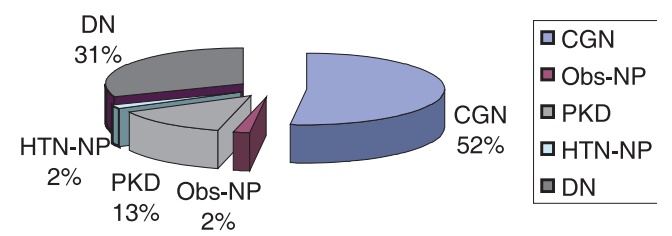

Fig-1: Relative distribution of causes of CKD in 52 patients. 
Table-I

\begin{tabular}{ll}
\multicolumn{2}{c}{ Characteristics of 52 CKD patients } \\
\hline Total number of cases & 52 \\
Male & $34(65.4 \%)$ \\
Female & $18(34.6 \%)$ \\
Mean age & $46.8 \pm 12.6$ years \\
Mean haemoglobin & $9.36 \pm 2.13 \mathrm{gm} / \mathrm{dl}$ \\
Mean serum creatinine & $8.0 \pm 4.2 \mathrm{mg} / \mathrm{dl}$ \\
\hline
\end{tabular}

Table-II

Mean serum iron profile of 52 CKD patients

\begin{tabular}{lll} 
& $\begin{array}{l}\text { All cases } \\
(\mathrm{n}=52)\end{array}$ & $\begin{array}{l}\text { Iron deficient } \\
\text { case }(\mathrm{n}=12)\end{array}$ \\
\hline S. iron $(\mathrm{ug} / \mathrm{dl})$ & 115.3 & 114.5 \\
TIBC $(\mathrm{ug} / \mathrm{dl})$ & 421.9 & 417.0 \\
S. ferritin $(\mathrm{ng} / \mathrm{ml})$ & 412.9 & 101.8 \\
TSAT $(\%)$ & 28.3 & 23.8 \\
\hline
\end{tabular}

Table-III

Comparison of serum ferritin and TAST with bone marrow iron status

\begin{tabular}{|c|c|c|c|c|c|c|}
\hline \multirow[t]{2}{*}{ Bone marrow iron status } & \multicolumn{3}{|c|}{ Serum ferritin } & \multicolumn{3}{|c|}{ TSAT } \\
\hline & $<100 \mathrm{ng} / \mathrm{ml}$ & $100-500 \mathrm{ng} / \mathrm{ml}$ & $>500 \mathrm{ng} / \mathrm{ml}$ & $<20 \%$ & $20-50 \%$ & $>50 \%$ \\
\hline Bone marrow iron present $n=40$ & 01 & 25 & 14 & 06 & 31 & 03 \\
\hline Bone marrow iron absent $n=12$ & 08 & 03 & 01 & 06 & 00 & 06 \\
\hline $\mathrm{n}=52$ & 09 & 28 & 15 & 12 & 31 & 09 \\
\hline
\end{tabular}

\section{Discussion:}

There are controversies prevailing about the best measure of the body iron status in CKD patients. In an otherwise healthy individual a TSAT of less than $16 \%$ and serum ferritin of less than $12 \mathrm{ng} / \mathrm{ml}$ indicates absolute iron deficiency. But in CKD patient, absolute iron deficiency is defined as having a serum ferritin level of less than $100 \mathrm{ng} / \mathrm{ml}$ and TSAT level of less than $20 \%{ }^{11}$. The concept of functional iron deficiency further complicates the scenario. As both the serum ferritin and TSAT levels are affected by many factors besides body iron store, new parameters of iron status particularly in CKD patients undergoing haemodialysis and/or receiving $\mathrm{rHuEPO}$ have been evaluated $^{8,9,10,12,13,14}$. But absence of iron deposits in the bone marrow is still considered as gold standard for absolute iron deficiency ${ }^{10}$.

$\mathrm{NK} / \mathrm{DOQI}$ has recommended the therapeutic range of TSAT between $20 \%$ and $50 \%$ and serum ferritin between 100 and $500 \mathrm{ng} / \mathrm{ml}^{11}$. In this study of 52 non-dialysis patients it was found that 43 patients had serum ferritin either within or above this therapeutic range. 28 patients had serum ferritin between 100 and $500 \mathrm{ng} / \mathrm{ml}$ and 15 patients had more than $500 \mathrm{ng} / \mathrm{ml}$.
Only nine patients had serum ferritin below 100 $\mathrm{ng} / \mathrm{ml}$. On the other hand low TSAT $(<20 \%)$ and high TSAT $(>50 \%)$ were found in 12 and nine cases respectively. Therapeutic range of TSAT was found in 31 cases. The mean serum ferrtitin and TSAT level in these cases were $412.9 \mathrm{ng} / \mathrm{dl}$ and $28.3 \%$. Thus, according to the NK/DOQI criteria, majority of study population were not actually iron deficient. These findings are in contrast with that of Gotloib et al who found mean serum ferritin and TSAT level of 235.9 $\mathrm{ng} / \mathrm{ml}$ and $13.5 \%$ in a study of 47 CKD patients 15 . This contradiction justifies the concept that serum ferritin and TSAT are not absolute reliable parameters for the body iron status. Stainable iron deposits in the bone marrow were also evaluated in all of the cases. Out of 52 cases stainable iron deposits were found in $40(77 \%)$ cases and absent in $12(23 \%)$ cases. In one study, no evidence of stainable iron deposits was found in 46 out of 47 CKD patients with anaemia 15 . Other studies found diminished iron store in $29 \%$ cases of renal transplantation patients and $23 \%$ cases of CRF patients 16,17. Mean serum ferritin level in iron deficient CKD patients was found to be $70 \mathrm{ng} / \mathrm{ml}$ in two studies that are in contrast to present findings 17, 18 . However, another study estimated diagnostic 
threshold of ferritin for iron deficiency as $80-350$ $\mathrm{ng} / \mathrm{ml}^{19}$. They also found absence of iron in $76.4 \%$ patients on maintenance haemodialysis ${ }^{19}$. Here higher value of mean serum ferritin and TSAT level of $101.8 \mathrm{ng} / \mathrm{ml}$ and $23.8 \%$ were found in 12 iron deficient patients. There were also high TSAT and high or normal serum ferritin in six $(50 \%)$ and four $(33.3 \%)$ cases respectively of the 12 patients having no iron deposits and that low TSAT and low serum ferritin in six and one cases respectively of those 40 patients having iron deposits in the marrow.

Therefore, it is concluded that though iron deficiency is said to be an important cause of anaemia in CKD, many patients may not have iron deficiency. It is also concluded that serum iron profile correlate less well with the bone marrow iron status and that serum iron profile may be misleading in evaluating the actual status of the body iron store particularly in pre dialysis chronic kidney disease patients.

\section{References}

1. Eschbach JW, Cook JD, Schribner BH, Finch CA. Iron balance in hemodialysis patients. Ann Intern Med 1977; 87: 710

2. Peco-Antic A. Management of renal anemia. Turk J Paed 2005; 47 (Suppl): S19-S27

3. Gutteridge MC, Rowly DA, Griffiths E et. al. Low molecular iron complexes and oxygen radical reactions in idiopathic haemochromatosis. Cin Sci 1985; 68: 463

4. Kuvibidila S. Iron deficiency, cell mediated immunity and resistance against infection: Present knowledge and controversies. Nutr Res 1987; 7: 989

5. Eschbach JW. Iron therapy and the anemia of ESRD, historical perspective. Semin Dial 1999; 12: 212-218

6. Barth RH. Iron metabolism in end-stage renal disease. Semin Dial 1999; 12: 224-230Nisse

7. National kidney Foundation. Kidney disease outcomes Quality Initiative: Clinical Practice guidelines for anemia of chronic kidney disease 2000. Am J Kidney Dis 2001; 37 (Suppl): S182-S238
8. Domrongkitchaiporn S, Jirakranont B, Atamasrikul K, et al. Indices of iron status in continuous ambulatory peritoneal dialysis patients. Am J Kidney Dis 1999; 34: 29-35

9. Rifkind D, Kraveltz HM, Knight V, Schade AL. Urinary excretion of iron binding protein in the nephrotic syndrome. N Engl J Med 1961; 256:115

10. Mittal S, Maesaka JK, Fishbane S. Diagnosis of iron deficiency in end-stage renal disease. Semin Dial 1999; 12 : 231-234

11. NKF-K/DOQI Clinical Practice Guidelines For Anemia Of Chronic Kidney Disease: New York, National Kidney Foundation, 2001

12. Tonbul HZ, Kaya H, Selcuk Y, et al. Serum transferring receptor level in the diagnosis of iron deficiency due to erythropoietin treatment. Nephron 1998; 80:241

13. Bovy C, Tsobo C, Crapanzano L, et al. Factors determining the percentage of hypochromic red blood cells in hemodialysis patients. Kidney Int 1999; 56: 1113-1119

14. Chen YC, Hung SC, Tarng DC. Association between transferin receptor-ferritin index and conventional measures of iron responsiveness in hemodialysis patients. AM J Kidney Dis; 2006: 47 (6): 1036-1044

15. Gotloib L, Silverberg D, Fudin R, Shostak A. Iron deficiency is a common cause of anaemia in chronic kidney disease and can be corrected with intravenous iron. J Nephrol 2006; 19(2): 161-167

16. Garewal G, Ahluwalia J, Kumar V et al. The utility of bone marrow examination in renal transplantaion: nine years of experience from north India. Transplantation 2006: 81(9): 134-136

17. Balaban EP, Sheehan RG, Demian SE et al. Evaluation of bone marrow iron stores in anaemia associated with chronic disease: a comparative study of serum and red cell ferritin. Am J Hematol 1993; 42(2): 177-181.

18. Witte DL, Angstadt DS, Davis SH et al. Predicting bone marrow iron stores in anemic patients in a community hospital using ferritin and erythrocyte sedimentation rate. Am J Pathol 1988; 90:85- 87.

19. Bell JD, Kincaid WR, Morgan RG et al. Serum ferritin assay and bone marrow iron stores in patients on maintenance hemodialysis. Kidney Int 1980; 17(2): 237-241. 